\title{
Preoperative prevalence of methicilline-resistant Staphylococcus aureus (MRSA) in non-hospitalized population in the Netherlands during a 5-year period
}

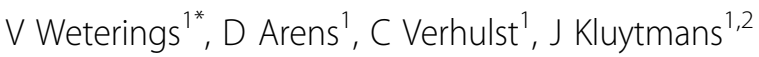 \\ From 3rd International Conference on Prevention and Infection Control (ICPIC 2015) \\ Geneva, Switzerland. 16-19 June 2015
}

\section{Introduction}

The MRSA Search-and-Destroy strategy relies on active screening of high risk groups. However, not all carriers belong to known risk groups and MRSA in the community is emerging also in the Netherlands.

\section{Objectives}

We conducted a retrospective, observational study to determine the prevalence of MRSA carriers in nonhospitalized cardiothoracic, interventional cardiologic, orthopaedic and vascular patients.

\section{Methods}

The study was performed in a large teaching hospital in the Netherlands. All samples of patients who were tested for preoperative $S$. aureus nose carriage from Mar 1, 2010 until Dec 31, 2014, were included. Nasal swabs (ESwab, Copan Diagnostics, Italy) were collected during preoperative assessments. Samples of cardiothoracic patients were tested by PCR (GeneXpert, Cepheid, CA), other samples were cultured using chromogenic agar plates. All MRSA isolates were confirmed using molecular methods. A questionnaire was conducted to ascertain potential MRSA risk factors and a linear regression analysis was used to examine trends in MRSA carriage

\section{Results}

In total, 18,298 nasal swabs were obtained from 14,552 unique patients. In 329 swabs (1.8\%) the GeneXpert gave an invalid result, therefore 17,969 swabs were

${ }^{1}$ Laboratory for Microbiology and Infection Control, Amphia Hospital, Breda, the Netherlands

Full list of author information is available at the end of the article included in our analysis. S. aureus was detected in 4604 patients $(25.6 \% 95 \%$ CI $25.0-26.3 \%)$ of which 26 were MRSA (0.14\% 95\% CI 0.10-0.22\%). Prevalence of MRSA carriage increased by a factor of 1.8 (from $0.12 \%$ in 2010 to $0.22 \%$ in 2014), however this increase was not significant $(\mathrm{p}=0.144$ using linear regression analysis). Twelve spa types were found: $34.6 \%$ belonged to t011, $15.4 \%$ to t002, $7.7 \%$ to t015, $7.7 \%$ to t018, $7.7 \%$ to t223, and $3.8 \%$ to t024, $\mathrm{t} 445, \mathrm{t} 447, \mathrm{t} 458, \mathrm{t} 688, \mathrm{t} 1154, \mathrm{t} 1784$ each. Two isolates were positive for the PVL gene(7.4\%). Results of the questionnaire revealed that $20 / 26$ patients had no known risk factors for MRSA carriage (0.11\% 95\% CI 0.07-0.17\%). In this group spa type t002 (36.4\%) and t011 (36.4\%) were most prevalent.

\section{Conclusion}

This study revealed a sustained low prevalence of MRSA carriage of $0.14 \%$ in non-hospitalized patients in a large teaching hospital, over 5 years. The high prevalence of spa type t011 in patients without livestock-associated (LA) risk factors, indicates that LA-MRSA is spreading to individuals in the community

\section{Disclosure of interest}

None declared.

\section{Authors' details}

'Laboratory for Microbiology and Infection Control, Amphia Hospital, Breda, the Netherlands. ${ }^{2} J u l i u s$ Center for Health Sciences and Primary Care, University Medical Center Utrecht, Utrecht, Netherlands.

Published: 16 June 2015 
doi:10.1186/2047-2994-4-S1-O4

Cite this article as: Weterings et al.: Preoperative prevalence of

methicilline-resistant Staphylococcus aureus (MRSA) in non-hospitalized

population in the Netherlands during a 5-year period. Antimicrobial

Resistance and Infection Control 2015 4(Suppl 1):04.

Submit your next manuscript to BioMed Central and take full advantage of:

- Convenient online submission

- Thorough peer review

- No space constraints or color figure charges

- Immediate publication on acceptance

- Inclusion in PubMed, CAS, Scopus and Google Scholar

- Research which is freely available for redistribution

Submit your manuscript at www.biomedcentral.com/submit
C Biomed Central 